\title{
Nitrate pollution of Neogene alluvium aquifer in Morogoro municipality, Tanzania
}

\author{
Irene KIBONA, Stelyus L. MKOMA* and Ibrahimu C. MJEMAH \\ Department of Physical Sciences, Faculty of Science, Sokoine University of Agriculture (SUA), P.O. Box 3038, \\ Morogoro, Tanzania. \\ "Corresponding author; E-mail: stelyusm@gmail.com; Tel: +25523260 3404; Fax: +255232603404
}

\begin{abstract}
Concern over nitrate pollution of groundwater in integrated water quality management has been growing recently. The levels of nitrate in wells from septic tanks and urban agriculture with nitrogen fertilizers application may increase the potential groundwater pollution by nitrate. The purpose of this study was to determine the concentrations and spatial distribution of nitrate $\left(\mathrm{NO}_{3}{ }^{-}\right)$in groundwater in Morogoro municipality. Groundwater samples were collected from 20 wells during wet season period in March-April 2010 in 6 wards namely Kihonda, Mji Mpya, Mafisa, Saba Saba, Boma and Kilakala. The spectrophotometer was used to measure the $\mathrm{NO}_{3}{ }^{-}$concentration in water samples. The minimum and maximum nitrate levels were 1.4 and $32.5 \mathrm{mg} / \mathrm{L}$ respectively in the wards studied with an average of $7.76 \mathrm{mg} / \mathrm{L}$. These results showed that all of the groundwater samples have $\mathrm{NO}_{3}{ }^{-}$concentration below the Tanzania Bureau of Standards upper limit value and World Health Organization guideline of $75 \mathrm{mg} / \mathrm{l}$ and $50 \mathrm{mg} / \mathrm{l}$ respectively. Also, the level of nitrate concentration tends to decrease with depth for most of the places due to the anoxic condition that is available at the higher depth which facilitates the utilization of nitrate by anaerobic microorganisms.
\end{abstract}

(c) 2011 International Formulae Group. All rights reserved.

Keywords: Nitrate levels, shallow wells, pollution, urban environment.

\section{INTRODUCTION}

Groundwater is a natural resource with both ecological and economic value which is of vital importance for sustaining life, health, agriculture and the integrity of ecosystems. Groundwater quality may be impacted by changes in overlying land use such as industrial development, agricultural activity and wastewater generation. The contaminants for which epidemiological studies have suggested a risk associated with their presence in potable water include arsenic, fluoride, lead, nitrate, pesticides, hydrocarbons and chlorinated hydrocarbons (Orebiyi et al., 2010). The most common contaminant identified in groundwater is dissolved nitrogen in the form of nitrate $\left(\mathrm{NO}_{3}{ }^{-}\right)$. It is well known that serious and occasionally fatal poisonings in infants have occurred following ingestion of well waters which contain more than 50 $\mathrm{mg} / \mathrm{N}_{3}^{-}$(WHO, 2007). Nitrate has been linked with gastric and oesophageal cancer, because of the reaction of nitrate with amines in the diet-forming carcinogenic nitrosamines. Further risks exist for pregnant women and for patients with gastric medical conditions, and with hemoglobinopathy (Gatseva and Argirova, 2008). Despite the World Health Organization's guidelines (WHO, 2007) for drinking water quality, nitrate levels in groundwater have been increasing over recent decades in most countries (Razowska-Jaworek and Sadurski, 2005; Barbooti et al., 2010; Jiban Singh et al., 2010).

In Africa, scarcity and water pollution constitute a major challenge for sustainable 
water resources management (Tredoux and Talma, 2006). In Tanzania, the government has passed a new Water Supply and Sanitation Act (URT, 2009) with a view to give effect to the National Water Policy (URT, 2002). The main aim of this law is to ensure the rights of every Tanzanian to have access to efficient, effective and sustainable water supply and sanitation services for all purposes by taking into account among others, protection and conservation of water resources and development and promotion of public health and sanitation. Though little studies of nitrate pollution have been done on a local scale in Tanzania (Mjemah, 2007; Kassenga and Mbuligwe, 2009), there is limited groundwater monitoring data to help manage the resource on a regional scale. The objective of this study was to determine the levels and spatial distribution of nitrate in wells at Morogoro municipality.

\section{MATERIALS AND METHODS}

Geological and hydrogeological settings The geology of the study area is composed of two geological units; the Precambrian Basement Complex, and the Neogene. The Precambrian basement known as Usagaran system covers a vast area in the basin, where the study area is located. It is the fundamental rock in the Uluguru Mountains and composed of high grade metamorphic rocks essentially granulites, gneisses and amphibolites of various compositions. In some places, these rocks are intercalated with marbles. The Neogene formation is composed of thick deposits of red soil occurring in the north-west of Morogoro Town; in the extreme north-west is the edge of the 'mbuga' soils and alluvium of the Wami Flats (not shown in the map since it is outside the study area). Generally, the Neogene formation is the one forming the major aquifers with potential water in the study area though its thickness in the study area is about $50 \mathrm{~m}$. The study area is crossed in the centre by Morogoro River and Ngerengere River, which both are originated from Uluguru Mountains as shown in Figure 1.

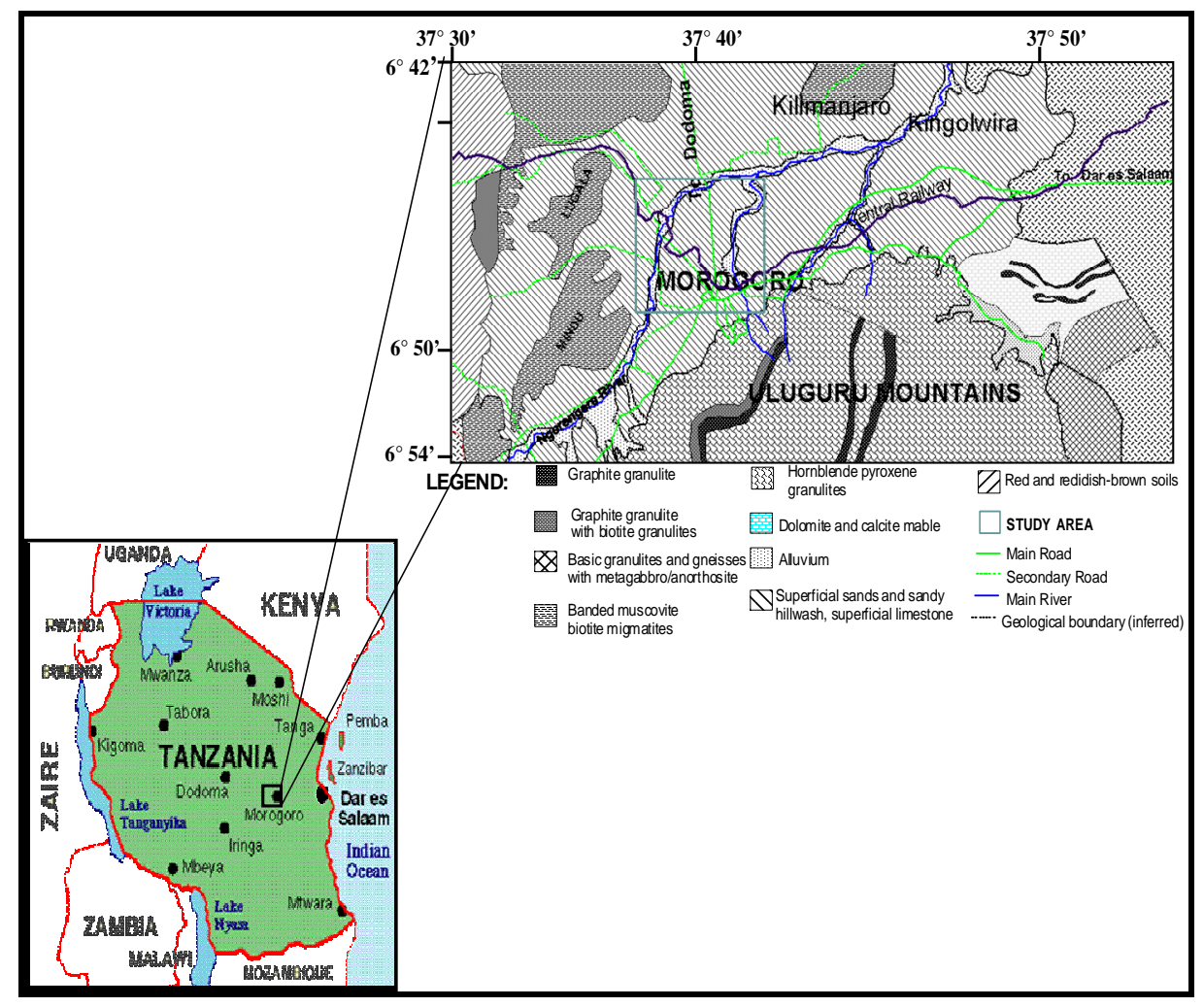

Figure 1: Morogoro geological map showing study area (Sampson, 1961). 


\section{Sample collection and analysis}

Groundwater samples were collected from the 20 water wells in Morogoro municipality (Figure 2). The water samples were collected once a month for each well during rain season in March and April 2010. Groundwater samples were transport to laboratory with ice bag and examined immediately. Most of the groundwater samples were collected from wells inside or close to residential and commercial areas; these wells were used mainly for potable supply, washing, and irrigation. Water samples were analyzed for $\mathrm{pH}$, electrical conductivity (EC), total dissolved solids (TDS) and nitrate $\left(\mathrm{NO}_{3}{ }^{-}\right)$as described in the
Standard Methods (2005). The pH and EC were measured in situ using $\mathrm{pH}$ and ECmeter. The TDS was analysed by TDS meter and nitrate analysis was done using Spectrophotometer analytical method in the laboratory of Morogoro Urban Water Supply and Sewerage Authority (MORUWASA). However, the spectrophotometric method with phenol disulphonic acid was used to analyze $\mathrm{NO}_{3}{ }^{-}$when salinity was too high for $\mathrm{NO}_{3}{ }^{-}$to be detected in a diluted sample. The information on groundwater use and screen depth was respectively obtained through communications with well owners and well lithology data.

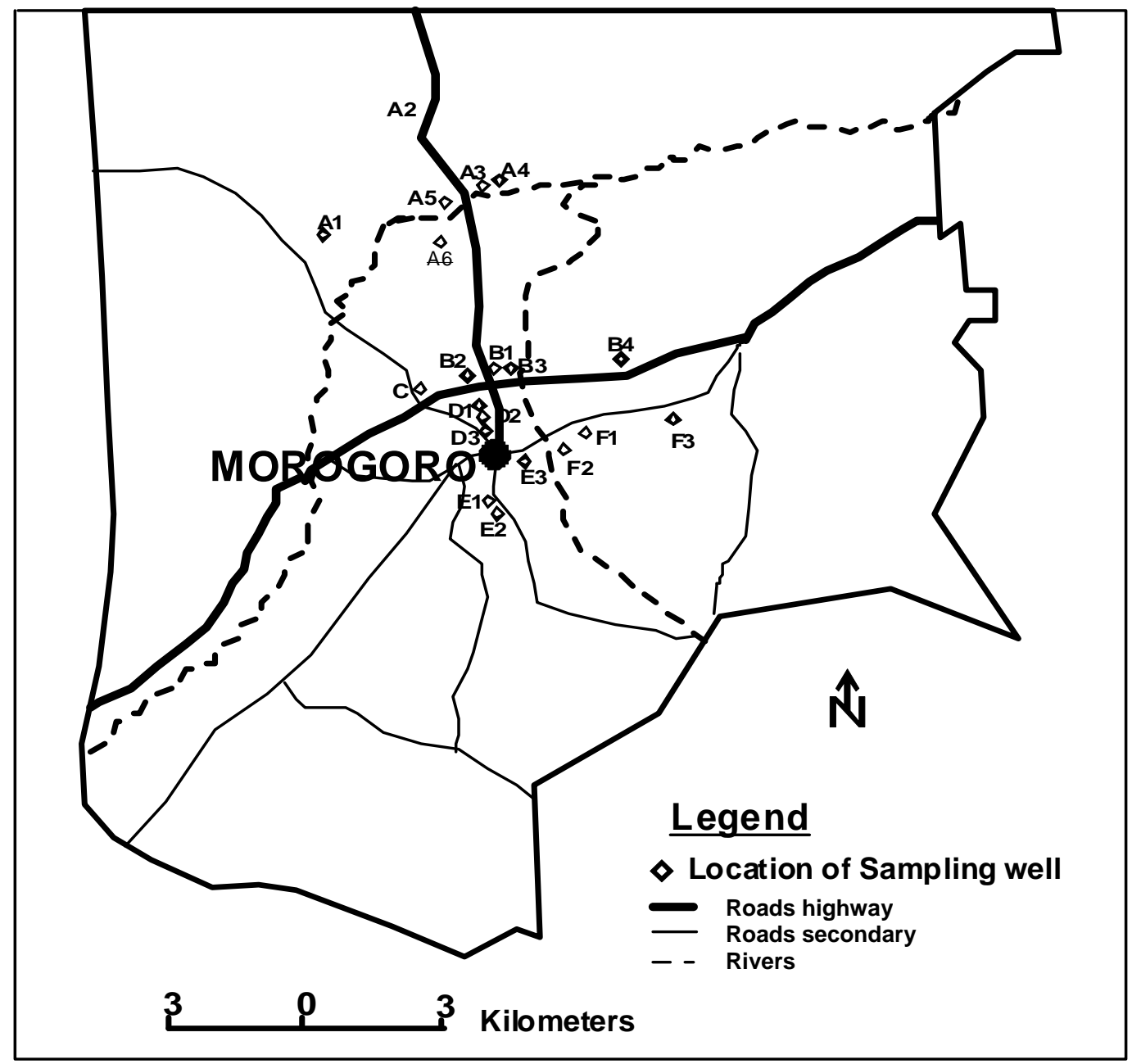

Figure 2: Location of groundwater sampling at Morogoro municipality. 


\section{RESULTS AND DISCUSSION}

Table 1 shows the results of chemical constituents, $\mathrm{pH}, \mathrm{EC}, \mathrm{TDS}$ and nitrate concentrations of groundwater samples from 20 wells in Morogoro municipality. The depths of the wells are also shown in Table 1.

\section{PH}

Measurement of $\mathrm{pH}$ is one of the most important and frequently used tests in water chemistry which related to the concentration of hydrogen ions in solution (Reeve, 2002). Table 1 shows the $\mathrm{pH}$ values obtained from this study area which ranged from 7.0 to 8.65 . According to the TBS (2005) lower and upper limits for quality of drinking water are 6.5 and 9.2 respectively. The results from the present study show that the observed $\mathrm{pH}$ can slightly increase the solubility of metal and precipitate heavy metal as hydroxides hence increase their groundwater contamination. Also, the weathering of minerals, such as limestone or dolomite, by water becomes more rapid with a decrease in $\mathrm{pH}$ (Reeve, 2002) which was not expected in this area. At low concentrations of hydrogen ions and low ionic strengths, which are typical of unpolluted environmental samples, the hydrogen ion activity is approximately equivalent to the hydrogen ion concentration. The biological effect of a change in $\mathrm{pH}$ can most easily be seen by the sensitivity of freshwater species to acid conditions. Lethal effects of $\mathrm{pH}$ on aquatic life occur below pH 4.5 and above $\mathrm{pH} 9.5$ (WHO, 2007).

\section{Total dissolved solids}

The substance remaining after evaporation and drying of a water sample is termed the "residue". The filterable residue is the Total Suspended Solids (TDS) which is a measure of the amount of dissolved material in the water column reported in milligrams per litre $(\mathrm{mg} / \mathrm{L})$. The most important aspect of TDS with respect to drinking water quality is its effect on clarity and taste. Also, the total amount of dissolved solids in groundwater is estimated by measuring the EC of the water, and this is often used as a rough indication of natural groundwater quality (Reeve, 2002). From this study, the values of TDS range from 332-2670 mg/L with an average of 1112.7 $\mathrm{mg} / \mathrm{L}$ (Table 1). Differences in TDS were also observed in some closely-spaced wells (Figure 2) and this is attributed either to the depth of the well or to interconnection with higher, more saline, strata. Contamination from external sources can also be an additional factor. The observed TDS levels are below the recommended limit for drinking water supplies. The palatability of drinking water with a TDS level less than $500 \mathrm{mg} / \mathrm{L}$ is generally considered to be good. Drinking water supplies with TDS levels greater than $1200 \mathrm{mg} / \mathrm{L}$ are unpalatable to most consumers (WHO, 2007). The principal constituents that contribute to elevated filterable residue values are usually dissolved salts such as calcium, magnesium, sodium, potassium, bicarbonate, chloride, sulphate and nitrate. High concentrations of TDS limit the suitability of water as a drinking source and irrigation supply (Razowska-Jaworek and Sadurski 2005).

\section{Electrical conductivity}

The ability of water to conduct an electric current is known as conductivity or specific conductance, and depends on the concentration of dissolved metals and other dissolved materials (ions) in solution (Reeve, 2002). Conductivity is measured in milisiemens per meter $(1 \mathrm{mS} / \mathrm{m}=10 \mu \mathrm{S} / \mathrm{cm})$. The EC measurement was made in the field immediately after water sampling, because conductivity changes with storage time and is also temperature-dependent. The spatial distribution of electrical conductivity (EC) from analysed groundwater samples across the study area is shown in Figure 3. Kihonda (ward A) depicted higher EC due to higher TDS and possibly salinity. The EC values ranged from 661 to $5350 \mu \mathrm{S} / \mathrm{cm}$ with an average of $2214.45 \mu \mathrm{S} / \mathrm{cm}$ (Table 1). The conductivity of natural waters is found to vary between 50 and $1500 \mu \mathrm{S} / \mathrm{cm}$ and generally EC is $<500 \mu \mathrm{S} / \mathrm{cm}$ except for areas very near to the Ocean were EC $>1500 \mu \mathrm{S} / \mathrm{cm}$ or even up 
to $5000 \mu \mathrm{S} / \mathrm{cm}$ because of the possible occurrence of coastal salinization (Reeve, 2002). In this study EC was well correlated with total dissolved solid $\left(r^{2}=0.99\right)$ from analysed groundwater samples across the area as shown in Figure 4. It is often possible to establish a correlation between conductivity and dissolved solids for a specific body of water [dissolved solids $=$ conductivity $\mathrm{x} 0.55$ to 0.9 (the factor most often used is 0.7 )]. The variation of the empirical factor, from 0.55 to 0.9 , depends on the ionic components in solution and on the temperature of measurement (Reeve, 2002).

\section{Groundwater nitrate concentration}

The nitrate concentrations of groundwater in 20 wells that were sampled in Morogoro municipality are shown in Table 1. The minimum and maximum nitrate levels were 1.4 and $32.5 \mathrm{mg} / \mathrm{L}$ respectively with an average of $7.76 \mathrm{mg} / \mathrm{L}$. The spatial distribution of $\mathrm{NO}_{3}{ }^{-}$from analysed groundwater samples across the study area is shown in Figure 3. The low concentration of $\mathrm{NO}_{3}{ }^{-}$in the area indicates the least anthropogenic sources of pollution. However, vegetables are the main urban agricultural activities in the Municipal which farmers use inorganic N-fertilizers (and organic manure) that can result in groundwater contamination in vulnerable hydrogeologic settings. In comparison, wards $\mathrm{A}, \mathrm{B}, \mathrm{C}, \mathrm{D}, \mathrm{E}$, and $\mathrm{F}$ show different mean in nitrate contents, 3.0, 3.8, 15.2, 3.1 and 148 $\mathrm{mg} / \mathrm{l}$ respectively. Of the six wards, the highest average nitrate concentration in groundwater was observed in ward D, followed by ward $\mathrm{F}, \mathrm{B}, \mathrm{E}$ and $\mathrm{A}$. The observed $\mathrm{NO}_{3}{ }^{-}$levels are lower than the Tanzania Bureau of Standard (TBS) upper permissible limit value and World Health Organization (WHO) guideline of 75 and 50 mg/L respectively (TBS, 2005; WHO, 2007) respectively.

\section{Variation of nitrate concentration with well depth}

Figure 5 shows the variation of $\mathrm{NO}_{3}{ }^{-}$ concentration with depth. It can be observed from the graph that the trend of $\mathrm{NO}_{3}{ }^{-}$is decreasing with depth, though there are some deep wells with high $\mathrm{NO}_{3}{ }^{-}$, however, this can be due to the multiple screens. The decrease of $\mathrm{NO}_{3}{ }^{-}$observed in the shallow wells as the depth increases is related to the anoxic condition. In anoxic condition, organic carbon tends to be oxidized preferentially by the electron acceptor that supplies most energy to the micro-organisms, namely oxygen. With an excess of organic carbon, aerobic bacteria use dissolved oxygen until it is depleted. Once oxygen concentrations are depleted, which mostly occurs in the deep aquifer, reduction of other electron acceptors (such as $\mathrm{NO}_{3}{ }^{-}$) becomes energetically favourable. Once oxygen is consumed, denitrifying-bacteria use nitrate as an electron acceptor; when the nitrate is depleted, reduction reactions proceed through manganese and then iron oxides.

Table 1: Physico-chemical parameters of groundwater samples from Morogoro municipality.

\begin{tabular}{lcccccc}
\hline Area & Well Code & Depth & pH & EC & TDS & Av. NO ${ }^{-}$Conc. \\
\hline Kihonda & A1 & M & & $\mu$ S/Cm & $\mathrm{mg} / \mathrm{L}$ & $\mathrm{mg} / \mathrm{L}$ \\
Kihonda & A2 & 61 & 8.17 & 4070 & 2030 & 15.3 \\
Kihonda & A3 & 55 & 8.65 & 1004 & 506 & 2 \\
Kihonda & A4 & 65 & 8.2 & 996 & 498 & 5 \\
Kihonda & A5 & 52 & 8.49 & 4300 & 2149 & 4.3 \\
Kihonda & A6 & 63 & 8.21 & 4600 & 2294 & 2.7 \\
Mafisa & B1 & 55 & 7.94 & 1660 & 827 & 4.2 \\
Mafisa & B2 & 65 & 7.75 & 897 & 451 & 2.2
\end{tabular}




\begin{tabular}{lcccccc} 
Mafisa & B3 & 50 & 7.32 & 3930 & 1980 & 7.5 \\
Mafisa & B4 & 52 & 7.27 & 2300 & 1150 & 1.4 \\
Saba Saba & C & 35 & 7.4 & 2730 & 1360 & 22.5 \\
Mji Mpya & D1 & 45 & 7.2 & 1799 & 906 & 14.1 \\
Mji Mpya & D2 & 33 & 7 & 2520 & 1307 & 21.8 \\
Mji Mpya & D3 & 48 & 7.8 & 1052 & 527 & 9.8 \\
Boma & E1 & 60 & 7.2 & 812 & 406 & 3.9 \\
Boma & E2 & 65 & 7.4 & 661 & 332 & 2.3 \\
Boma & E3 & 58 & 7.2 & 1263 & 640 & 3.2 \\
Kilakala & F1 & 52 & 7.2 & 1524 & 778 & 2.8 \\
Kilakala & F2 & 37 & 7 & 1627 & 835 & 32.5 \\
Kilakala & F3 & 48.5 & 7.2 & 1194 & 608 & 9 \\
\hline
\end{tabular}

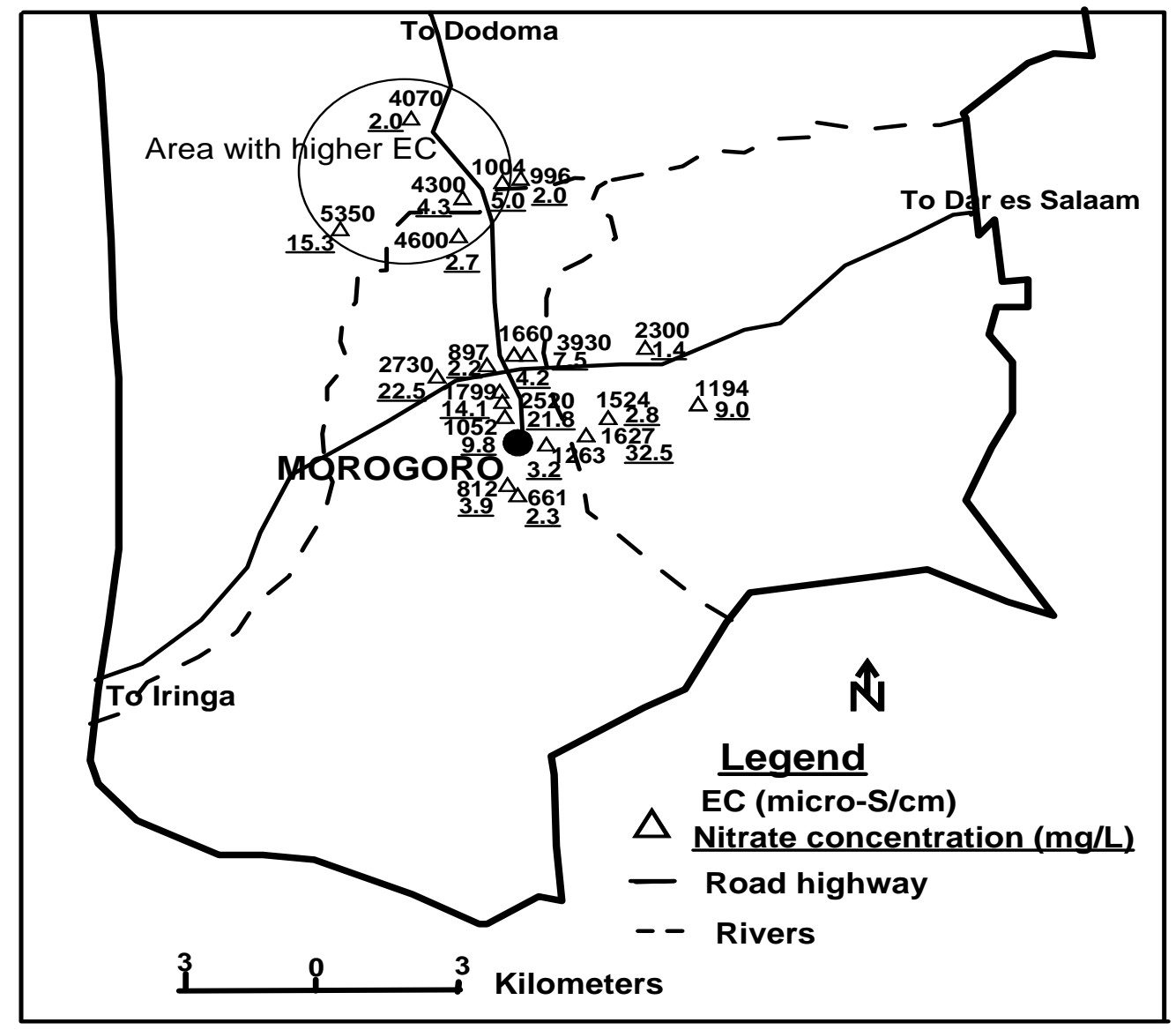

Figure 3: The EC (measured at $25^{\circ} \mathrm{C}$ in $\mu \mathrm{S} / \mathrm{cm}$ ) and $\mathrm{NO}_{3}{ }^{-}$concentration $(\mathrm{mg} / \mathrm{L})$ of groundwater in Morogoro municipality. 


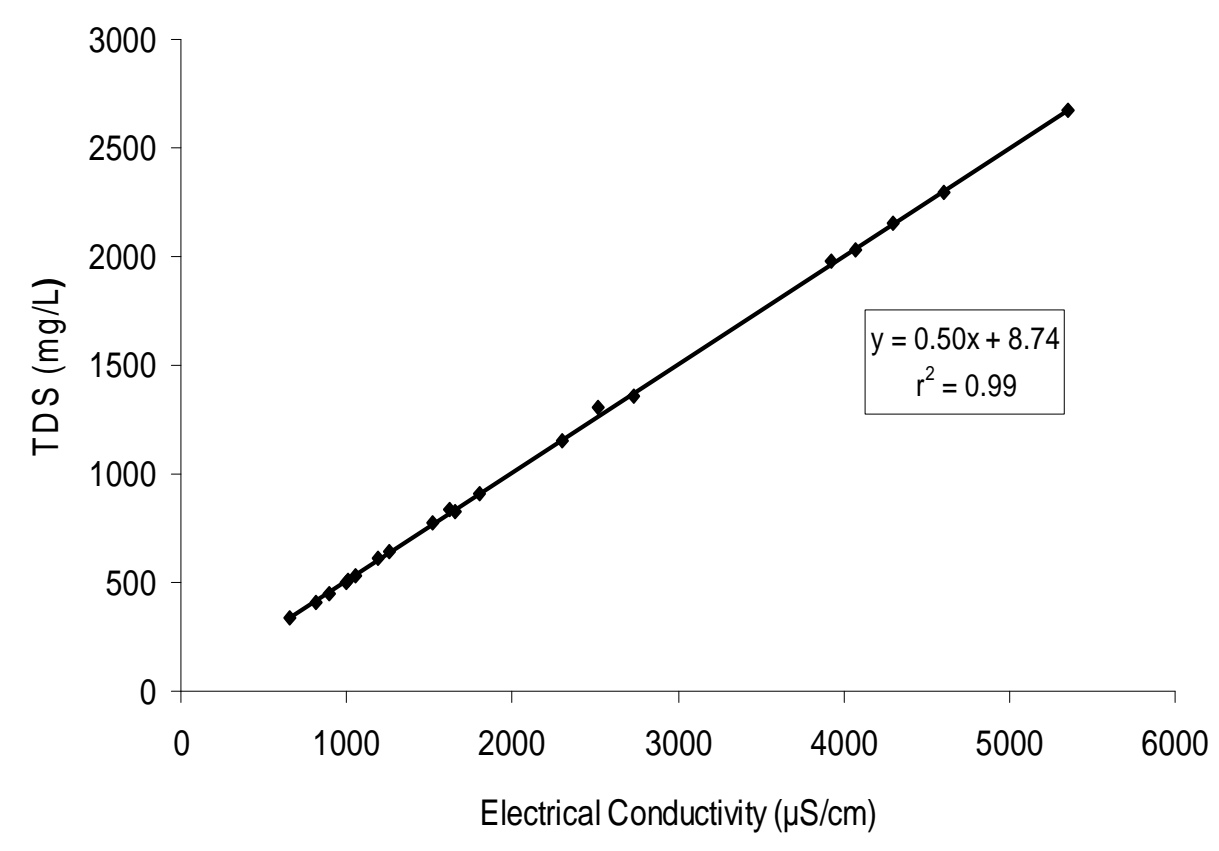

Figure 4: The correlation between EC and TDS of the aquifer at Morogoro municipality.

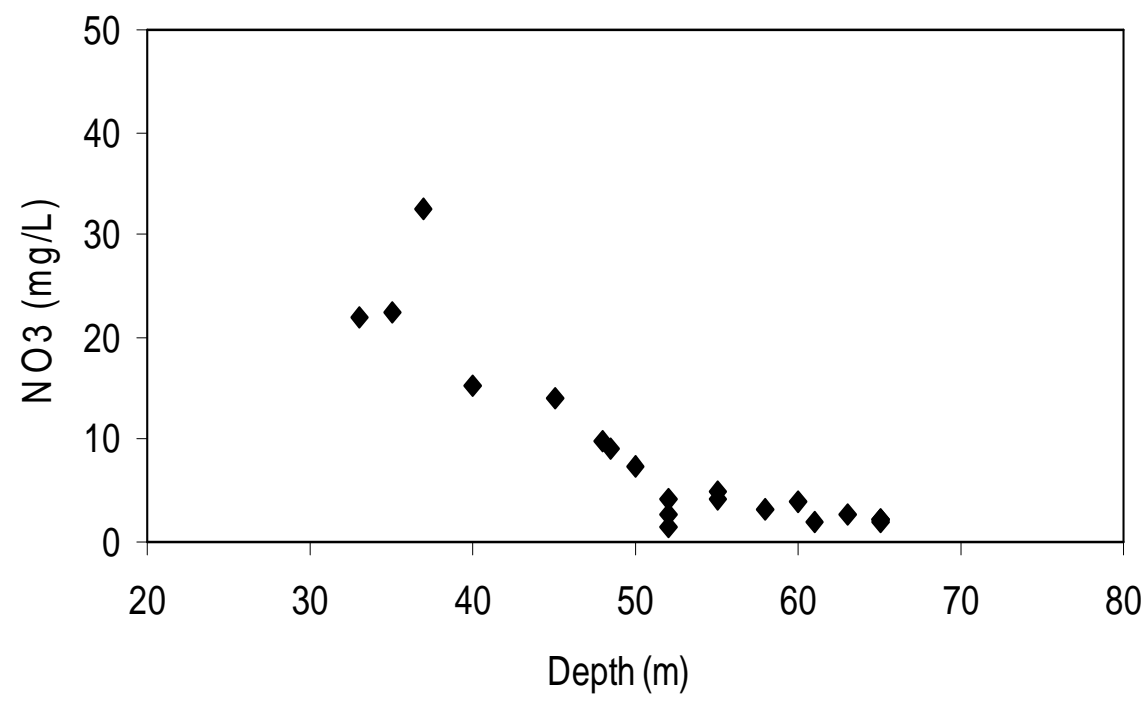

Figure 5: The variation of $\mathrm{NO}_{3}{ }^{-}$concentration with depth. 


\section{Conclusion}

The objective of this study was to assess the groundwater pollution of nitrate in Morogoro municipality. The magnitude of the pollution in this area depends on human activities, including agriculture and livestock breeding. The results show that high nitrate concentration occurred mainly in wells with depths less than $41 \mathrm{~m}$. However, all groundwater samples in the selected wards have nitrate concentration below the TBS standard and WHO guideline. The high nitrate concentration in the study site is contributed by large volumes of wastewater from septic tanks. Although groundwater is not only commonly used as drinking water in Morogoro municipality, nitrate in groundwater remains a critical issue associated with mass transport, waterway transformation, and interactions of surfacegroundwater. The Ministry of Health, Ministry of Water and irrigation, and the National Environment Management Council (NEMC) should work very closely to enforce appropriate pieces of legislation in order to ensure protection of groundwater resources. All wastewater should be treated before being discharged into the environment. Further study of all major ions for ionic balance and their seasonal variations are needed to better judge the reliability of the chemical analysis.

\section{ACKNOWLEDGMENTS}

The authors acknowledge the financial support of the Sokoine University of Agriculture for granting special research fund to the first Author. We would also like to thank Mr. F. Mahai and Mr. Ng'ana from Morogoro Wami-Ruvu basin water office in Water Resources Monitoring and Assessment section (WRMA) for help in logistics.

\section{REFERENCES}

Barbooti MM, Bolzoni G, Mirza IA, Pelosi M. Barilli I, Kadhum R, Peterlongo G. 2010. Evaluation of quality of drinking water from Baghdad, Iraq. Sci. World J., 5(2): 35-46.

Gatseva PD, Argirova MD. 2008. High-nitrate levels in drinking water may be a risk factor for thyroid dysfunction in children and pregnant women living in rural Bulgarian areas. Int. J. Hygiene Environ. Health, 211(5-6): 555-559.

Jiban Singh M, Davis D, Somashekar R.K, Prakash KL, Shivanna K. 2010. Environmental isotopes investigation in groundwater of Challaghatta valley, Bangalore: A case study African $J$. Environ. Sci. Technol., 4(4): 226-233.

Kassenga GR, Mbuligwe SE. 2009. Comparative Assessment of Physicochemical Quality of Bottled and Tap Water in Dar Es Salaam, Tanzania. Int. J. Biol. Chem. Sci., 3(2): 209-217.

Mjemah IC. 2007. Hydrogeological and hydrogeochemical investigation of a coastal aquifer in Dar-es-Salaam, Tanzania. PhD Thesis, Ghent University, p. 222.

Orebiyi EO, Awomeso AJ, Martins O, Idowu AO, Oguntoke O, Taiwo, AM. 2010. Assessment of Pollution Hazards of Shallow Well Water in Abeokuta and Environs. Am. J. Environ. Sc., 6(1): 5056.

Razowska-Jaworek L, Sadurski A. 2005. Nitrates in Groundwater: Selected Papers from the European Meeting of the International Association of Hydrogeologists, Wisla, Poland, 4-7 June 2002. AA Balkema Publishers: The Netherlands.

Reeve RN. 2002. Introduction to Environmental Analysis. John Wiley \& Sons, Ltd.: England.

Sampson DN, Wright AE. 1961. Morogoro Geological Map, Quarter Degree Sheet 183, Geological Survey Division, Dodoma, Tanganyika.

Standard Methods. 2005. Standard methods for the examination of water and 
wastewater. Nitrates (Centennial Ed.). Baltimore, Maryland, United States of America.

Tanzania Bureau of Standards (TBS). 2005. National Environmental Standards Compendium: TZS 789. Drinking (potable) water - Specification; 74 .

Tredoux G, Talma AS. 2006. nitrate pollution of groundwater in Southern Africa. In Groundwater Pollution in Africa, Xu Y, Usher B (eds). Taylor and Francis/Balkema: Leiden, The Netherlands; $15-36$.
United Republic of Tanzania (URT). 2002. National Water Policy, Ministry of Water and Livestock Development, Dodoma.

United Republic of Tanzania (URT). 2009. Water Supply and Sanitation Act, Ministry of Water and Irrigation, Dar es Salaam.

World Health Organisation. 2007. Nitrate and nitrite in drinking water. Background document for development of World Health Organization Guidelines for drinking-water quality (WHO/SDE/WSH/ 07.01/16). Geneva, Switzerland: World Health Organization; 1-21. 